Regeda-Furdychko M. M. The influence of thiotriazoline on the indicators of nitric oxide under the condition of experimental contact dermatitis and experimental pneumonia. Journal of Education, Health and Sport. 2020;10(2):35-40. eISSN 2391-8306. DOI http://dx.doi.org/10.12775/JEHS.2020.10.02.004

https://apcz.umk.pl/czasopisma/index.php/JEHS/article/view/JEHS.2020.10.02.004

https://zenodo.org/record/3637411

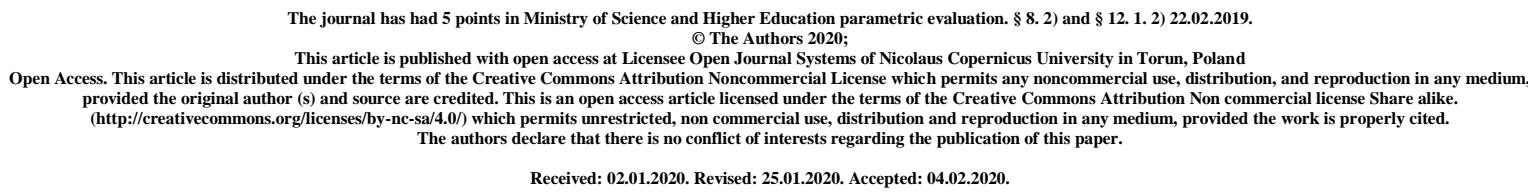

The influence of thiotriazoline on the indicators of nitric oxide under the condition of experimental contact dermatitis and experimental pneumonia

\title{
M. M. Regeda-Furdychko
}

\section{Lviv Medical Institute}

\begin{abstract}
As a result of the conducted researches it is established that with the development of experimental contact dermatitis and experimental pneumonia there is an increase in the level of stable metabolites of nitric oxide, increase of activity of total NO synthase and, at the same time, inhibition of L-arginine activity in the blood, thus these indicators were most expressed on the late stages of her forming of combine pathology ( $18^{\text {th }}$ day). The use of thiotriazoline in curative aims stipulated the decline of stable NO metabolites on $31.9 \%(\mathrm{p} \leq 0.05)$, NOS in blood on $26.6 \%\left(\mathrm{p}_{1} \leq 0.05\right)$ and increase of content L-arginine on $34.5 \%\left(\mathrm{p}_{1} \leq 0.05\right)$ at experimental contact dermatitis and experimental pneumonia as compared to the group of animals that did not yield to influence of this preparation.
\end{abstract}

Key words: contact dermatitis; pneumonia; nitric oxide; thiotriazoline. 
Вплив тіотриазоліну на показники системи оксиду азота за умов формування експериментального контактного дерматиту та експериментальної пневмонії

Регеда-Фурдичко М. М.

\section{Львівський медичний інститут}

Резюме. У результаті проведених досліджень встановлено, що за умови розвитку експериментального контактного дерматиту та експериментальної пневмонії спостерігається підвищення рівня стабільних метаболітів оксиду азоту, зростання активності сумарної NO-синтази та, водночас, пригнічення активності L-аргініну в крові, причому ці показники були найбільше виражені на пізніх етапах формування комбінованої патології (18-а доба). Використання тіотриазоліну з лікувальною метою зумовило зниження рівня стабільних метаболітів на $31,9 \%\left(\mathrm{p}_{1} \leq 0,05\right)$, вмісту NOS у крові на $26,6 \%\left(\mathrm{p}_{1} \leq 0,05\right)$ та зростання L-аргініну на $34,5 \%\left(\mathrm{p}_{1} \leq 0,05\right)$ в порівнянні 3 групою тварин, які не піддавалися впливу цього препарату. Отже, як показують отримані дані, застосування тіотриазоліну показало його коригуючий вплив на змінені показники метаболізму оксиду азота в периферійній крові морських свинок за умов розвитку експериментального контактного дерматиту та експериментальної пневмонії.

Ключові слова: контактний дерматит; пневмонія; оксид азоту; тіотриазолін.

Влияние тиотриазолина на показатели системы оксида азота в условиях формирования экспериментального контактного дерматита и экспериментальной пневмонии

\section{Регеда-Фурдичко М. М.}

\section{Львовский медицинский институт}

Резюме. В результате проведенных исследований установлено, что в условиях развития экспериментального контактного дерматита и экспериментальной пневмонии наблюдается повышение уровня стабильных метаболитов оксида азота, повышение активности суммарной NO-синтазы и одновременно подавление активности L- 
аргинина в крови, причем эти показатели были больше всего выражены на поздних этапах формирования комбинированной патологии (18-е сутки). Использование тиотриазолина в лечебных целях обусловило снижение уровня стабильных метаболитов на $31,9 \%\left(\mathrm{p}_{1} \leq 0,05\right)$, содержимого NOS в крови на $26,6 \%\left(\mathrm{p}_{1} \leq 0,05\right)$ и рост Lаргинина на $34,5 \% \quad\left(\mathrm{p}_{1} \leq 0,05\right)$ по сравнению с группой животных, которые не поддавались влиянию этого препарата. Следовательно, как показывают полученные данные, применение тиотриазолина показало его корректирующее влияние на измененные показатели метаболизма оксида азота в периферийной крови морских свинок при условиях развития экспериментального контактного дерматита и экспериментальной пневмонии

\section{Ключевые слова: контактный дерматит; пневмония; оксид азота;} тиотриазолин.

Introduction. The problem of a pathogenesis, early diagnosis and timely treatment of a pneumonia has become of particular importance and is one of the topical in modern pulmonology. In recent years, knowledge about the development of the inflammatory process in general and pneumonia in particular has been expanded [9]. However, the mortality rate is still 13-15 per 100000 population, accounting for 3\% of those with pneumonia. In the practical work of a physician-therapist, there are often cases of combined pathology of the respiratory organs and concomitant pathology that complicate and alter the clinical course of the underlying disease.

As a pathophysiological model for comorbid pathology we chose pneumonia and contact dermatitis. In the modern world, it is difficult to overestimate the impact of the environment and occupational hazards on human health, which has led to a significant increase in the incidence and prevalence of contact dermatitis [3].

According to current research, nitric oxide (NO) is considered as an important physiological regulator of functions and metabolic processes in cells. In the mechanisms of $\mathrm{NO}$ formation, the major role is played by the aminoacid L-arginine in the presence of nitricoxidase synthetases (NOS). The NO / NOS system is able to influence the activity of the major systems of the body $[2,4]$.

$\mathrm{NO}$ at high concentrations initiates processes of oxidative and nitrosative stress that lead to impaired prooxidant-antioxidant balance. As a result, the activation of apoptotic mechanisms and the initiation of destructive processes in cells, leading to the progression of dysfunction. The clarification of these issues will help to identify new links in pathogenesis in 
combined pathology, will help to develop criteria that will allow predicting the course of the disease and the effectiveness of pharmacotherapy [5].

The study of the effectiveness of the complex of tools that would simultaneously repair damaged cell membranes, had antioxidant effect, corrected disorders of the nitric oxide system, the immune system is promising. In this regard, our attention is drawn to the drug thiotriazoline, which has immuno-correcting, membrane-stabilizing and antioxidant properties.

The aim of our research was to determine the changes in the parameters of the system of nitric oxide in Guinea pig blood with experimental contact dermatitis (ECD) and experimental pneumonia (EP) before and after treatment with thiotriazoline.

Materials and methods. Researches were conducted on guinea pigs, divided into six groups: I - control, II $-4^{\text {th }}$ day of the expirement, III $-8^{\text {th }}$ day of contact dermatitis development and experimental pneumonia, IV $-10^{\text {th }}$ day and $\mathrm{V}-18^{\text {th }}$ day of model processes and VI group - guinea pigs with ECD and EP after the treatment with thiotriazoline during 10 days (from $8^{\text {th }}$ to the $18^{\text {th }}$ days of the experiment). For the purpose of detailed analysis and interpretation of nitric oxide indicators in different days of the experiment, two periods of the development of ECD and EP were distinguished: early and late. The chosen days of ECD and EP were due to the classical stages of the inflammatory process. Early period included groups of animals on the $4^{\text {th }}$ and $8^{\text {th }}$ days of experiment. The late one - guinea pigs on the $10^{\text {th }}$ and $18^{\text {th }}$ days of ECD and EP.

Experimental contact dermatitis was simulated by the method of VA Volkovoj (2010) [10]. EP was called by the method of VN Shlyapnikov, TL Solodov (1998) [6]. Thiotriazoline was administered intramuscularly at a dose of $100 \mathrm{mg}$ per $1 \mathrm{~kg}$ of weight daily from the $8^{\text {th }}$ to the $18^{\text {th }}$ days of the experiment. Activity of NO synthases was detected by VV Sumbaev method [8], L-arginine content in the blood serum - by TL Aleinikov method [1], stable NO metabolites - by HHW Schmidt [7]. All digital results of the investigation were processed statistically by Student's method.

Results of the study and their discussion. The studying of nitric oxide metabolism in guinea-pigs that were suffered from experimental contact dermatitis and experimental pneumonia showed some shifts of all indicators which we determined in different periods.

Thus, at the initial stage of our modelling process and in the further researches we found a significant increase in the level of stable metabolites $\left(4^{\text {th }}, 8^{\text {th }}, 10^{\text {th }}\right.$ and $18^{\text {th }}$ days $)$ by $66.4 \%(\mathrm{p} \leq 0.05), 88.2 \%(\mathrm{p} \leq 0,05), 101.6$ and $111.7 \%(\mathrm{p} \leq 0.05)$ compared with the control group. 
When studying the level of activity of total nitric oxide synthase (endothelial and inducible) in guinea pigs with ECD and EP, it was found that at all stages of its formation there were significant changes of indicators in comparison with the control group. In the early period $\left(4^{\text {th }}, 8^{\text {th }}\right.$ days $)$ of the experiment, we observed an increase of NOS by $23.5 \%(p \leq 0.05)$, $33.8 \%(\mathrm{p} \leq 0.05)$ in contrast to intact animals. The late period is characterized by a significant progression of the studied indicator, namely a rise of $105.8 \%(p \leq 0.05)$ and $120.5 \%(p \leq 0.05)$ respectively at $10^{\text {th }}$ and $18^{\text {th }}$ days compared to the first group of animals, which leads to excess formation of nitric oxide in blood lymphocytes, which, in turn, stimulates the development of oxidative and nitrosative stress, which will aggravate the violation of the prooxidant-antioxidant balance.

When assessing the activity of the content of L-arginine, its decline in the dynamics of the formation of ECD and EP was recorded, namely by $4^{\text {th }}, 8^{\text {th }}, 10^{\text {th }}$ and $18^{\text {th }}$ days decreased by $40.0 \%, 48.5 \%, 62.3 \%$ and $68.7 \%$, respectively $(\mathrm{p} \leq 0.05)$.

The therapeutic use of thiotriazoline resulted in a decrease in stable metabolites by $31.9 \%\left(\mathrm{p}_{1} \leq 0.05\right)$, total NOS activity by $26.6 \%\left(\mathrm{p}_{1} \leq 0.05\right)$ and increase of L-arginine content in the blood by $34.5 \%\left(\mathrm{p}_{1} \leq 0.05\right)$ against a group of guinea pigs with ECD and EP before therapy (fig.1).

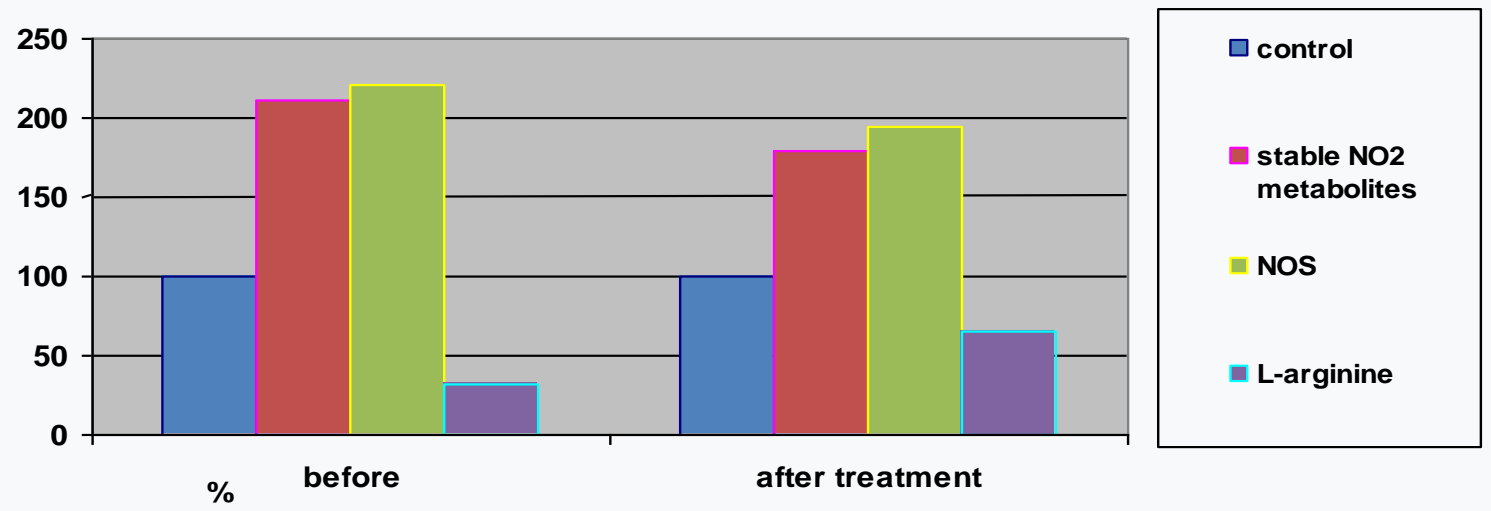

Fig. 1. The influence of thiotriazolin on the level of indices of nitric oxide system in guinea pigs' blood in the ECD and EP formation dynamics.

Conclusions. Researches revealed changes in the activity of the system of nitric oxide in the blood, namely the increase of the level of stable metabolites and the growth of the activity of total NO synthase, which is accompanied by the compensatory inhibition of the 
activity of L-arginine, and these indicators were most pronounced at the later stages of experimental contact dermatitis and experimental pneumonia (18 ${ }^{\text {th }}$ day). The use of thiotriazoline showed its corrective effect on altered indicators of metabolism of nitric oxide in peripheral blood of guinea pigs under conditions of development of ECD and EP.

\section{REFERENCES}

1. Aleinikova TL., Rubtsova G. V., Pavlova N. A. Guide to practical classes in biochemistry M .: Medicine. 2000.128 p.

2. Aminuddin F, Enelund A.-C, Eriksson B., et. al. Nitric oxide synthase polymorphisms, gene expression and lung function in chronic obstructive pulmonary disease. BMC Pulmonary Medicine. 2013;13:64.

3. Kostner, L., Anzengruber, F., Guillod, C., Recher, M., SchmidGrendelmeier, P., \& Navarini, A. A. (2017). Allergic contact dermatitis. Immunology and Allergy Clinics, 37 (1), 141-152.

4. Li, H., Horke, S., \& Förstermann, U. (2014). Vascular oxidative stress, nitric oxide and atherosclerosis. Atherosclerosis, 237 (1), 208-219.

5. Faro, M. L. L., Fox, B., Whatmore, J. L., Winyard, P. G., \& Whiteman, M. (2014). Hydrogen sulfide and nitric oxide interactions in inflammation. Nitric Oxide, 41, 3847.

6. Shlyapnykov V.N., Solodova T.L. et al. Eksperimentalnye modeli ostrykh pnevmoniy, vyzvanykh uslovno-patolohicheskimi bakteriyami I ikh assotsiatsiey: metod. ukazaniya sost. Saratov, 1998. 30 p.

7. Schmidt H. H. W. Determination of Nitrite and Nitrate in Culture Media. Acta Biochemica. 1995. No. 2.P. 323-327.

8. Sumbaev VV., Yasinskaya IM Influence of DDT on activity of nitric oxide synthase in the rats'liver, lungs and brain. Contemporary problems of toxicology. 2000. No. 3. P. 3-7.

9. Tramper-Stranders G.A. Childhood community-acquired pneumonia: a review of etiology and antimicrobial treatment studies.Paediatr Respir Rev, 26 (2018), pp. 41-48

10. Volkova V.A., Kuchynska I.V., Tiupka T.I. Study of the therapeutic efficacy of a new ointment with a lipophilic complex of the Tremulin aspen bark under conditions of non-allergic contact dermatitis in rats. Pharmacology and drug toxicology. 2010;7-12. 